\title{
Tuberculous Lymphadenitis of Hilar Lymph Nodes as a Cause of Right Middle Lobe Syndrome: A Case Report
}

\author{
Sağ Orta Lob Sendromuna Neden Olan Hiler Lenf Nodu Tüberküloz \\ Lenfadeniti: Olgu Sunumu
}

Shital Patil', Mazhar Mirza ${ }^{2}$

\section{Abstract}

Right middle lobe syndrome (RMLS) is a rare but important clinical entity that is characterized by recurrent or chronic collapse of the middle lobe of the right lung, but which may also involve the lingula of the left lung. In this case report, a 52 -year-old female presented with typical constitutional symptoms of tropical disease like cough, fever, and shortness of breath. Chest radiology documented RMLS and bronchoscopy was key to the evaluation of this case, as a sputum examination was inconclusive. Transbronchial needle aspiration (TBNA) of the lymph node and bronchoalveolar lavage (BAL) specimens were tested and Mycobacterium tuberculosis (MTB) of the hilar lymph nodes on the right side was confirmed using the GeneXpert MTB/RIF assay. Four antituberculosis treatment drugs were initiated and maintained for a total of 8 months with steroids as an adjunct in tapering dosages for 4 weeks. Complete clinical and radiological recovery was documented and confirmed bronchoscopically. A high index of suspicion is important when managing RMLS cases and all possible measures should be taken to confirm diagnosis.

Key words: RMLS (Right middle lobe syndrome), tuberculous lymphadenitis, Bronchoscopy, BAL, Gene Xpert MTB/RIF.

\section{Özet}

Orta lob sendromu (OLS) nadir görülen ve sağ akciğer orta lobda bazen de sol akciğer lingulada tekrarlayan veya kronik kollaps ile karakterize önemli bir klinik tablodur. Burada, öksürük, ateş, nefes darlığı gibi tropikal bir hastalığın tipik semptomları olan 52 yaşındaki bir kadın olgu sunulmaktadır. Balgam örnekleri yetersiz olduğu için grafideki OLS'yi belirlemek amacıyla bronkoskopik inceleme yapıldı. Transbronşial lenf nodu iğne aspirasyonu ve bronkoalveoler lavaj alındı. M. tuberculosis, lenf bezinde GeneXpert MTB/RIF assay ile saptandı. Dört haftada azaltılan dozlarda steroid ile beraber dörtlü antitüberküloz tedavi başlandı ve 8 ay sürdürüldü. Tam bir klinik ve radyolojik iyileşme görüldü ve bronkoskopik olarak da iyileşme saptandı. OLS için yüksek şüphe duyulan olgularda tanı için tüm tetkikler yapılmalıdır.

Anahtar Sözcükler: OLS (Orta lob sendromu), tüberküloz lenfadenit, bronkoskopi, BAL, Gene Xpert MTB/RIF

\footnotetext{
'Department of Pulmonary Medicine, MIMSR Medical College, Latur, Maharashtra, India

${ }^{2}$ Department of Internal Medicine, MIMSR Medical College, Latur, 'MIMSR Tıp Fakültesi, Göğüs Hastalıkları Anabilim Dalı, Latur, Maharaștra, Hindistan

${ }^{2}$ MIMSR Tıp Fakültesi, i̇ç Hastalıkları Anabilim Dalı, Latur, Maharashtra, India Maharaştra, Hindistan
}

Submitted (Başvuru tarihi): 23.04.2017 Accepted (Kabul tarihi): 02.10.2017

Correspondence (iletişim): Shital Patil, Department of Pulmonary Medicine, MIMSR Medical College, Latur, Maharashtra, India

e-mail: drsvpatil1980@gmail.com 
In 1948, Graham et al. (1) reported 12 patients with atelectasis and nontuberculous pneumonitis of the middle lobe of the right lung, which Effler and Ervin (2) subsequently termed middle lobe syndrome (MLS). There is limited literature on MLS, likely due to the multiple etiologies, varied presentation, and lack of a consistent clinical definition $(3,4)$. The most common definition of MLS is recurrent or chronic collapse of the middle lobe of the right lung. Although originally described as occurring only in the middle lobe, it can involve the lingula as well, which is sometimes called lingula syndrome (5). Pulmonary symptoms are common in MLS, but some patients are asymptomatic and the disease is only detected with chest radiography (6). The epidemiology of MLS is not well described. It occurs in children and adults of both sexes, in both primary and tertiary care settings $(7,8)$.

In a community-based study, out of the 30,588 persons who underwent annual mini chest roentgenography, $0.17 \%$ had MLS diagnosed with chest X-ray films (4). The incidence was significantly higher in persons over 50 years of age than in those under 50 years of age $(0.26 \%$ vs. $0.02 \%)$, and was higher in females than in males $(0.20 \%$ vs. $0.11 \%)(9)$.

\section{CASE}

A 52-year-old female, a housekeeper by occupation, and a non-addict, presented at the MIMSR medical college outdoor clinic of pulmonary medicine with complaints of a cough ongoing for 8 weeks. It was initially dry and continuous, but sputum developed in 2 weeks. The sputum was whitish-yellow originally, but became greenishyellow and increased in volume over 6 weeks, without hemoptysis. She also reported shortness of breath that was grade I (SJRQ) at first, and progressed to grade IV over a period of 6 weeks. A fever had also been present for 6 weeks that was initially low grade and intermittent with minimal chills and without rigors, but which increased in frequency and duration with a predominant surge in the late evening and overnight.

The patient was hospitalized in an indoor unit and a thorough medical examination and evaluation was performed and do

cumented. Pallor was present, without cyanosis or clubbing, and there was no generalized lymphadenopathy. A respiratory system examination revealed decreased breath sounds in the mammary and infra-axillary area on the right side, and in the mammary and infrascapular area on the left side, while the rest of the lung fields over both sides were normal. Bilateral coarse crackles and wheeze were also detected on auscultation.

The hematological parameters were: hemoglobin level of $7.2 \mathrm{gm} / \mathrm{dL}$; white blood cell count of $15600 / \mathrm{mm} 3$; platelet count of 5.6 lacs; peripheral smear indicated hypochromic, microcytic anemia; blood sugar level (random) of $118 \mathrm{mg} / \mathrm{dL}$; normal liver function and kidney function tests; and HIV Tri-Dot test was non-reactive. Sputum smear examinations for acid-fast bacillus (AFB) stain done on 3 occasions (2 consecutive early morning samples and 1 spot specimen) were negative. A chest $X$-ray was performed in the posteroanterior (PA) view and revealed triangular opacity in the right mid-lower zone in the paracardiac area obliterating the cardiac border on the right side with an obvious silhovette sign secondary to collapse with consolidation of the right middle lobe. Evidence of a shift of a major fissure upward and a minor fissure downward are direct signs of right middle lobe collapse, also seen clearly in the chest $X$-ray film. Homogeneous parenchymal infiltrates were seen in the right upper and lower zones. The cardiac border on the left side was not clearly demarcated and was blurred due to opacification in the lingular segment, i.e., the silhovette sign was also positive on the left side (Figure 1).

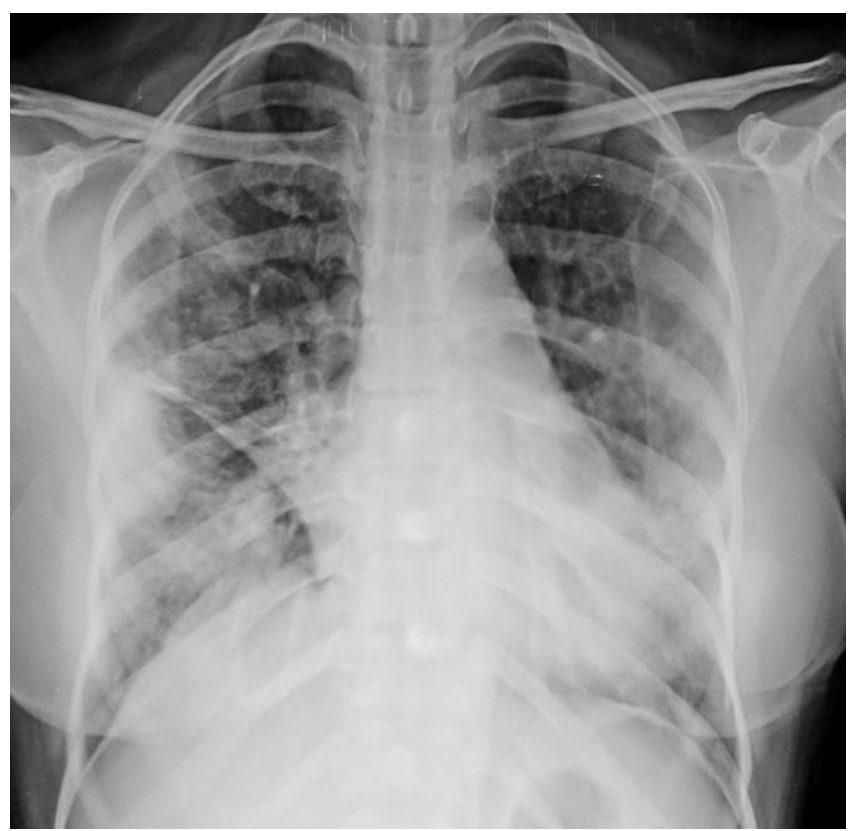

Figure 1: Triangular opacity in the right, mid-lower zone of the paracardiac area can be seen obscuring the cardiac border on the right side with an obvious silhouette sign, secondary to collapse, with consolidation of the right middle lobe

The treatment protocol administered in the hospital included parenteral administration of amoxicillin/clavulanic acid 3 times and a single $500 \mathrm{mg}$ dose of oral macrolide azithromycin. 
Fiberoptic bronchoscopy was used to determine the exact cause of the right middle lobe collapse. A Fujinon EPX $201 \mathrm{H}$ (Fujifilm Holdings Corp., Tokyo, Japan) system is routinely used in our bronchoscopy unit for all interventional diagnostic procedures, such as bronchial wash, bronchial brush, transbronchial needle aspiration (TBNA) cytology, forceps biopsy, and transbronchial lung biopsy, and we also have access to trained expertise in histopathology. A bronchoscopy image showed an edematous, partially blocked lumen of the right middle lobe. No endobronchial growth or intraluminal mucosal abnormality was observed. There was an intraluminal bulge seen at the opening of the right middle lobe leading to the blockage. The other openings of the right lower lobe were without any gross visible abnormality (Figure 2). A transbronchial lung biopsy (TBLB) was performed by passing forceps through the middle lobe bronchus lumen and 3 TBLB specimens were collected. A conventional TBNA was performed by passing a TBNA needle across the right middle lobe bronchus opening at the superior area where a bulge was visible. Bronchial wash fluid was also collected before and after procedures like TBLB and TBNA by instilling $80 \mathrm{~mL}$ of saline. One bronchoalveolar lavage (BAL) aliquot was used for an AFB smear, a second for cytology for malignant cells, and the third for BAL GeneXpert MTB/RIF analysis. The results of BAL cytology and smear for AFB were inconclusive. The TBLB and TBNA specimens were sent for histopathology and cytology evaluation and were confirmed as a chronic inflammatory pathology without any clear evidence of tuberculosis or malignancy.

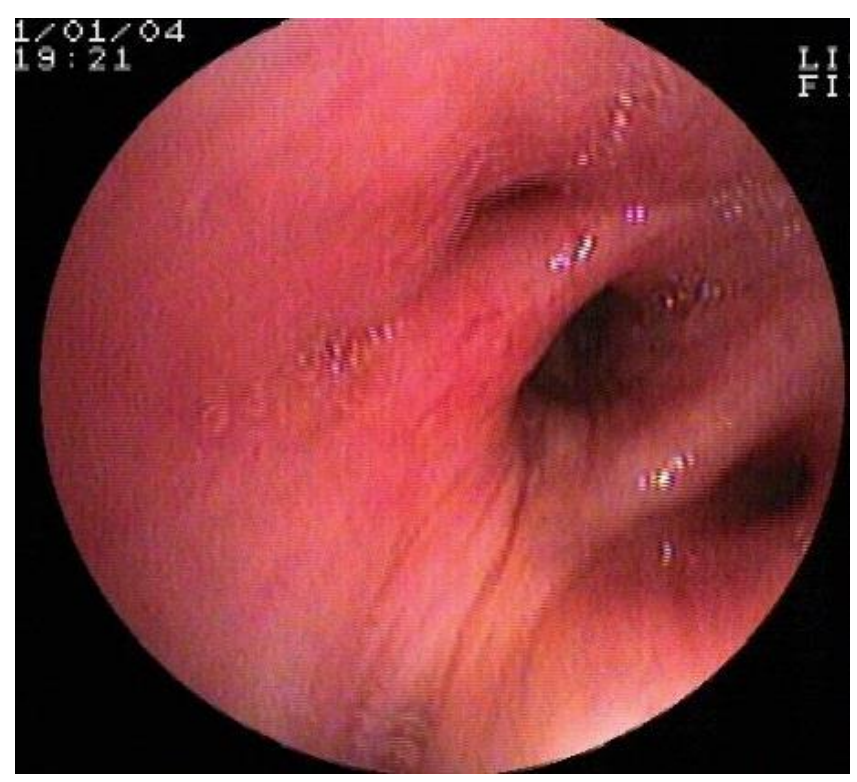

Figure 2: Bronchoscopy image showing edematous, partially blocked lumen of the right middle lobe
The results of the TBNA specimen with BAL sent for GeneXpert MTB/RIF analysis were positive for the Mycobacterium tuberculosis (MTB) genome with no detectable resistance to the rifampicin (RIF) gene (rpoB).

The 4-drug anti-tuberculosis treatment (ATT) composed of isoniazid, RIF, ethambutol, and pyrazinamide, was administered daily for 2 months, followed by isoniazid and RIF for 4 months, to complete 6 months standardized chemotherapy. Steroid adjunct therapy of prednisolone $15 \mathrm{mg}$ daily for 2 weeks, $10 \mathrm{mg}$ daily for 1 week, and 5 $\mathrm{mg}$ daily for 1 week was provided to avoid residual fibrosis, bronchostenosis, and stricture.

The patient was discharged home after ATT with strict advice to maintain the regimen of medicines as prescribed and follow-up to assess liver function for any side effects and to perform a chest $\mathrm{X}$-ray after 1 month for radiological response assessment. In Figure 3 , a decrease in opacification of the bilateral lung fields, a decrease in the density and opacification of the paracardiac triangular area on the right side, and similar findings on the left side of the paracardiac area can be seen.

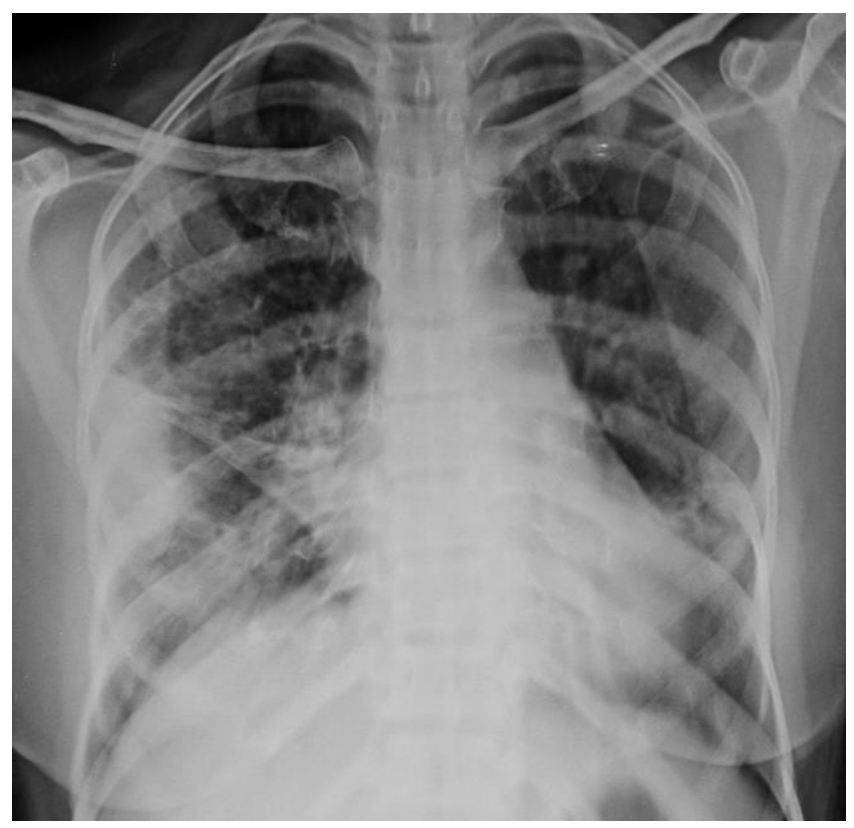

Figure 3: Image demonstrating a decrease in opacification in the bilateral lung fields, a decrease in paracardiac triangular opacity on the right side, particularly the density and size of opacification, and similar findings in the left paracardiac area (after 1 month of therapy)

A satisfactory clinical response in form of decreased cough, fever, and shortness of breath was observed in 4 weeks; the radiological response was delayed and took 5 months for near total response. In Figure 4, a near total resolution of the radiological abnormalities on both sides is visible, especially the triangular opacity of the right 
middle lobe collapse. Minimal parenchymal infiltrates were present in the right paracardiac area.

The ATT was extended from 6 months to 8 months total duration to document complete radiological resolution. Complete radiological response was observed after 8 months of therapy. Bronchoscopy was repeated at the conclusion of the ATT, and a complete response without any residual fibrosis or stricture was documented.

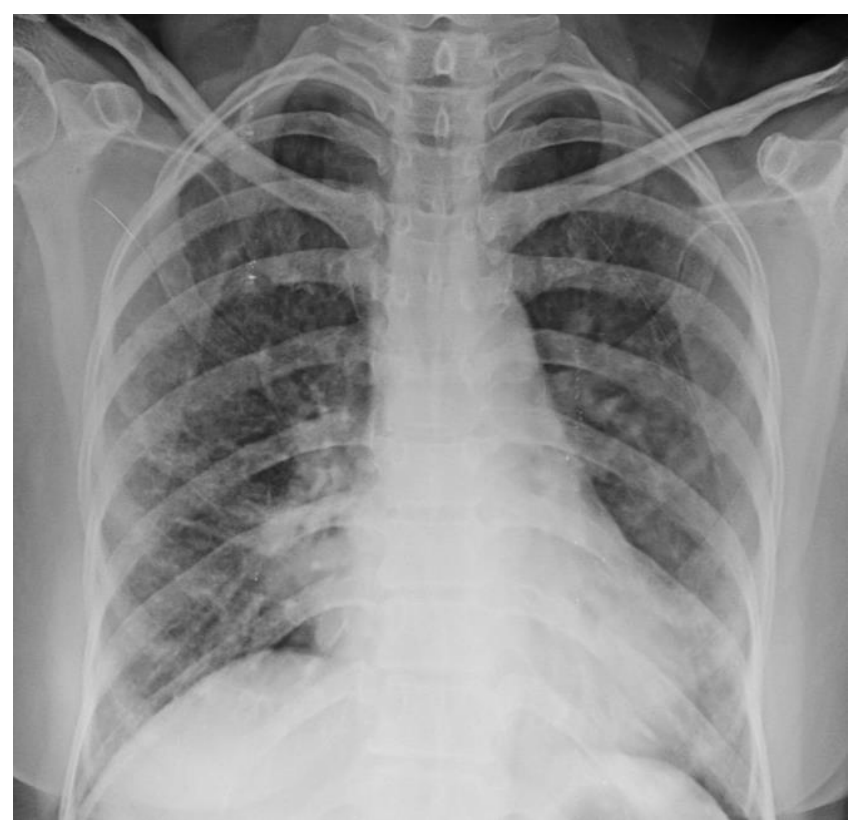

Figure 4: Image illustrating near-total resolution of radiological abnormalities on both sides, particularly the triangular opacity of the right middle lobe collapse. Minimal parenchymal infiltrates were present in the right paracardiac area (after 6 months of therapy)

\section{DISCUSSION}

RMLS is defined as recurrent or chronic collapse of the middle lobe of the right lung (10). MLS is divided pathophysiologically into obstructive and non-obstructive types. Obstructive MLS can be caused by endobronchial lesions or extrinsic compression of the right middle lobe bronchus. Tumors, both benign and malignant, have been estimated to account for about one-quarter of cases of MLS3, but it is important to note that many MLS studies have excluded patients with identifiable neoplasms $(1,3)$. Hamartoma can be a benign cause of obstruction, but malignant causes include primary lung cancer and metastases $(3,10)$. The most common cause of extrinsic compression of the right middle lobe bronchus is enlargement of the peribronchial lymph nodes (4). This can be due to granulomatous infections that cause adenopathy, such as histoplasmosis, but other fungal infections and both typical and atypical mycobacterial infections are also well-described etiologies of obstructive MLS $(3,11,12)$. Furthermore, adenopathy due to sarcoidosis or lymph node metastases has also been described in obstructive MLS (13). Other less common causes of obstruction of the right middle lobe bronchus include aspirated foreign objects (particularly in children), broncholiths that erode endobronchially from adjacent calcified lymph nodes, inspissated mucus associated with cystic fibrosis or allergic bronchopulmonary aspergillosis, and endoluminal granulomas associated with sarcoidosis (14) In the non-obstructive type of MLS, the right middle lobe bronchus is patent with no demonstrable obstruction on bronchoscopy $(7,8,15)$. This form of MLS is not restricted to the middle lobe and may be found in other lobes, most often the lingula of the left upper lobe (5). The nonobstructive form has also been called peripheral MLS and occurs in the majority of patients with $\operatorname{MLS}(3,6)$.

Certain anatomical characteristics make the middle lobe and lingula susceptible to transient obstruction as a result of inflammation or edema. This is probably related to the embryological development of the lungs (16). In the early embryonic phase, the smaller left endodermal lung bud is directed more laterally than the caudally located right bud. Thus, the asymmetry of the main bronchi, as present in adults, is established early in lung development. At the next stage of development, the right main lung bud forms 3 further lung buds and the left side only 2, corresponding to the later pulmonary lobes. The narrow diameter and long length of the middle lobar bronchus, combined with an acute take-off angle, create poor conditions for drainage $(3,5,8,16)$. Furthermore, the deep fissures of both the middle lobe and lingula, with only scanty parenchymal bridges, provide barriers to collateral ventilation (5). This can contribute to poor clearance of mucus with peripheral plugging of the small airways (16). The poor collateral ventilation of the middle lobe, especially in patients with complete fissures, and relative anatomical isolation reduce the chance of reinflation once atelectasis has occurred $(2,17)$.

Reich and Johnson (18) hypothesized that women were more likely to regard expectoration as socially unacceptable behavior and so they may habitually suppress a voluntary cough, which can lead to an inability to clear secretions (especially from the middle lobe and lingula), resulting in a chronic nidus for inflammation that favors subsequent infection. Pomerantz et al. (19) described most of their patients as slender women with skeletal abnormalities (e.g., pectus excavatum, mild scoliosis, straight back syndrome, mitral valve prolapse). It has also been associated with the continuous use of antitussive drugs. 
MLS is more common in females; the ratio of females to males ranges from 1.5 to 3 in most studies $(3,4,6,8)$. The most common symptoms are chronic or recurrent cough, observed in $30 \%$ to $50 \%$ of patients $(3,7)$; dyspnea; chest pain; audible wheezing; and fever and chills related to obstructive pneumonia $(3,7,15,20)$. These symptoms are often intermittent and recurrent. There is frequently a history of multiple treatments for recurrent pneumonia or asthma where antibiotics, mucolytics, and bronchodilators have been used (6). Hemoptysis, weight loss, fatigue, and low-grade fever are symptoms that may indicate complications related to suppurative infections $(2,4)$. A physical examination may be completely normal, but loss of breath sounds and vocal fremitus in the right middle lobe may also be apparent $(2,6)$.

Chest radiographs may be normal in patients with intermittent or recurrent collapse (6). Most often, however, patients have abnormalities on the chest radiograph that are most apparent in the lateral view (5). The volume loss resulting from collapse of the right middle lobe is seen as a triangle of increased density between the minor fissure and the lower half of the major fissure $(5,20)$. Its apex is at the hilum, and the base is peripherally located toward the pleura. With long-standing collapse, this radiographic density may have a width of only 2 to $3 \mathrm{~mm}$ (5). The PA radiograph may also show obfuscation of the right cardiac border (silhovette sign) $(5,20)$.

PA chest radiographs of RML atelectasis have been classified into 4 types (21). In Type 1, no abnormalities were detected, or only slight obliteration of the right cardiac border was seen. In Type 2, a triangular opacity was seen with its base on the right cardiac border. In Type 3, a band-like opacity was seen along the right cardiac border. In Type 4, there was a small, vague opacity near the right cardiac border.

The visualization of minor fissure and right cardiac border was not taken into consideration in this classification (21). Flexible bronchoscopy (FB) is important in the evaluation of patients with MLS, especially regarding the patency of the right middle lobe bronchus $(7,12)$. In addition to excluding malignancy or other surgically correctable lesions, FB allows for the collection of specimens for diagnosis of infectious causes (22). Studies have shown that bronchoscopy findings are abnormal in up to $40 \%$ of cases $(7,12)$. Stenosis of the middle lobe bronchus and ostial tumors is the most commonly encountered abnormality (23).

Kim et al. (13) observed that edematous-type endobronchial tuberculosis (EBTB) was much more common than actively caseating-type EBTB presenting as RMLS. Since the RML bronchus has a narrowed orifice, even a mild edematous change can lead to obstruction of the bronchial lumen. Due to the anatomical character of the right middle lobe, edematous-type EBTB is the most common type of EBTB presenting as RMLS.

Most cases of MLS receive treatment that is directed at the underlying cause, and this is true for both the obstructive and non-obstructive form. Patients with nonobstructive MLS usually respond to medical therapy with bronchodilators, mucolytic agents, and antibiotics (15). Antibiotic treatment is usually recommended to attempt to eradicate an infection that can be associated with bronchiectasis (8). However, the role of antibiotic therapy in the treatment of MLS is not well studied (3). Low-dose macrolide therapy can be used, particularly if bronchiectasis is present. Consideration must also be given to unusual infections (atypical mycobacteria, fungi) that may require specific antimicrobial agents $(12,13)$.

Systemic corticosteroid administration with ATT has been shown to more rapidly reduce TB symptoms, but its effect in preventing bronchial stenosis in EBTB remains doubtful (24). A prospective study with 34 EBTB patients revealed that systemic steroid treatment had no significant effect on preventing bronchial stenosis (25).

There are no data from randomized, controlled studies to determine the proportion of patients that require surgery because conservative treatment has failed. In addition, the role of FB and antibiotics in the management of MLS is constantly evolving. Surgical removal of the middle lobe is reserved for resistant and complex cases of MLS, usually for patients with isolated MLS who do not respond to medical therapy and who have proven obstruction of the middle lobe bronchus (8).

In this case report, near total resolution of right middle lobe consolidation and collapse was observed following medical treatment consisting of ATT administered for 8 months and systemic corticosteroids for 4 weeks.

\section{CONCLUSION}

Although TB is an endemic disease in India, TB of the hilar lymph nodes causing RMLS can be missed due to a variable clinical and radiological presentation. Delay in diagnosis, due to a lack of expertise in chest radiology or clinical suspicion is the most common reason for a poor outcome in TB. Typical triangular opacity of right middle lobe collapse on a chest radiograph mandates bronchoscopy to look for an endobronchial, mucosal, or peribronchial cause of RMLS. Bronchoscopy is less invasive, and is 
a rapid and sensitive technique to diagnose RMLS. Although role of bronchoscopy in sputum-negative pulmonary TB is well documented, it is still underutilized in India It can be used for the diagnosis, treatment, and in the assessment of response to treatment, especially in cases of RMLS.

GeneXpert is a rapid, sensitive, and specific assay, not just for the detection of MTB, but also for RIF resistance. It is an alternative to conventional tests that is reliable and can be performed on all bronchoscopic samples, such as BAL and TBNA specimens. GeneXpert should be used in sputum-negative pulmonary TB cases when conventional diagnostic tests are less sensitive and more timeconsuming.

\section{CONFLICTS OF INTEREST}

None declared.

\section{AUTHOR CONTRIBUTIONS}

Concept - S.P., M.M.; Planning and Design - S.P., M.M.; Supervision - S.P., M.M.; Funding - S.P.; Materials - S.P.; Data Collection and/or Processing - S.P.; Analysis and/or Interpretation - S.P.; Literature Review - S.P.; Writing S.P.; Critical Review - S.P.

\section{YAZAR KATKILARI}

Fikir - S.P., M.M.; Tasarım ve Dizayn - S.P., M.M.; Denetleme - S.P., M.M.; Kaynaklar - S.P.; Malzemeler - S.P.; Veri Toplama ve/veya İşleme - S.P.; Analiz ve/veya Yorum - S.P.; Literatür Taraması - S.P.; Yazıyı Yazan - S.P.; Eleştirel İnceleme - S.P.

\section{REFERENCES}

1. Graham EA, Burford TH, Mayer JH. Middle lobe syndrome. Post Grad Med 1948; 4:29-34. [CrossRef]

2. Effler DB, Ervin JR. The middle lobe syndrome; a review of the anatomic and clinical features. Am Rev Tuberc $1955 ; 71: 775-84$.

3. Bertelsen S, Struve-Christensen E, Aasted A, Sparup J. Isolated middle lobe atelectasis: aetiology, pathogenesis, and treatment of the so-called middle lobe syndrome. Thorax 1980; 35: 449-52. [CrossRef]

4. Culiner MM. The right middle lobe syndrome, a nonobstructive complex. Dis Chest 1966; 50:57-66. [CrossRef]

5. Ayed AK. Resection of the right middle lobe and lingula in children for middle lobe/lingula syndrome. Chest 2004; 125:38-42. [CrossRef]
6. Fraser R, Pare J, Pare P, Frazer R, Generoux G: Roentgenologic signs in the diagnosis of chest disease; in Fraser RG, et al (eds): Diagnosis of Diseases of the Chest. Philadelphia, Saunders, 1988.

7. Dees SC, Spock A. Right middle lobe syndrome in children. JAMA 1966; 197:8-14. [CrossRef]

8. Einarsson JT, Einarsson JG, Isaksson $H$, Gudbjartsson $T$, Gudmundsson G. Middle lobe syndrome: a nationwide study on clinicopathological features and surgical treatment. Clin Respir J 2009; 3:77-81. [CrossRef]

9. Iwata $M$, Ida M, Takeuchi E, Nakamura Y, Horiguchi T, Sato A. Middle lobe syndrome: incidence and relationship to atypical mycobacterial pulmonary disease. Nihon Kyobu Shikkan Gakkai Zasshi 1996; 34:57-62.

10. Wagner RB, Johnston MR. Middle lobe syndrome. Annal Thorac Surg 1983; 35:679-86. [CrossRef]

11. Bradham RR, Sealy WC, Young WG Jr. Chronic middle lobe infection. Factors responsible for its development. Ann Thorac Surg 1966; 2:612-6. [CrossRef]

12. Kala J, Sahay S, Shah A: Bronchial anthracofibrosis and tuberculosis presenting as a middle lobe syndrome. Prim Care Respir J 2008; 17:51-5. [CrossRef]

13. Kim HC, Kim HS, Lee SJ, Jeong YY, Jeon KN, Lee JD, et al: Endobronchial tuberculosis presenting as right middle lobe syndrome: clinical characteristics and bronchoscopic findings in 22 cases. Yonsei Med J 2008; 49: 615-9. [CrossRef]

14. Oshima M, Maeda $H$, Furonaka $O$, Doi M, Nishizaka $T$, Kuwabara M. Sarcoidosis with multiple organ involvement emerging as Lofgren's syndrome. Intern Med 2003; 42: 534-7.

15. Gudmundsson G, Gross TJ. Middle lobe syndrome. Am Fam Physician 1996; 53:2547-50.

16. Berrocal T, Madrid C, Novo S, Gutierrez J, Arionilla A, Gomez-Leon N. Congenital anomalies of the tracheobronchial tree, lung, and mediastinum: embryology, radiology, and pathology. Radiographics 2004; 24:e17. [CrossRef]

17. Inners CR, Terry PB, Traystman RJ, Menkes HA. Collateral ventilation and the middle lobe syndrome. Am Rev Respir Dis 1978; 1 18:305-10.

18. Reich JM, Johnson RE. Mycobacterium avium complex pulmonary infection presenting as isolated lingular or middle lobe pattern. The Lady Windermere syndrome. Chest 1992; 101:1605-9.

19. Pomerantz M, Denton JR, Huitt GA, Brown JM, Powell LA, Iseman MD. Resection of the right middle lobe and lingula for mycobacterial infection. Ann Thorac Surg 1996; 6:990-3. [CrossRef] 
20. McElvein RB, Mayo P. Middle lobe disease. South Med J 1967; 60:1029-32. [CrossRef]

21. Miyazaki A, Ashizawa K, Mori M, Ohtsubo M. Right Middle Lobe Atelectasis: Chest Radiographic and CT Appearances Correlating with the Clinical Features. Acta Med. Nagasaki 2003; 48:159-66.

22. Rock MJ. The diagnostic utility of bronchoalveolar lavage in immunocompetent children with unexplained infiltrates on chest radiograph. Pediatrics 1995; 95:373-7.
23. Erelel M, Yakar F, Yakar A. Endobronchial tuberculosis with lobar obstruction successfully treated by argon plasma coagulation. South Med J 2009; 102:1078-81. [CrossRef]

24. Cisneros JR, Murray KM. Corticosteroids in tuberculosis. Ann Pharmacother 1996; 30:1298-303. [CrossRef]

25. Park IW, Choi BW, Hue SH. Prospective study of corticosteroid as an adjunct in the treatment of endobronchial tuberculosis in adults. Respirology 1997; 2:275-81. [CrossRef] 